\title{
Transcription Factor MafG
}

National Cancer Institute

\section{Source}

National Cancer Institute. Transcription Factor MafG. NCI Thesaurus. Code C18047.

Transcription factor MafG (162 aa, $\sim 18 \mathrm{kDa}$ ) is encoded by the human MAFG gene. This protein plays a role in the regulation of globin gene expression. 